\title{
Antagonistic Effects of Java against Plant Parasitic Nematodes
}

\author{
Angélica Miamoto ${ }^{1}$, Cláudia Regina Dias-Arieira ${ }^{2}$, Heriksen Higashi Puerari ${ }^{1}$, Thaísa Muriel Mioranza ${ }^{1}$ \\ \& Carolina Bertuzzi Pereira ${ }^{1}$ \\ ${ }^{1}$ State University of Maringá, Post-Graduate in Agronomy, Maringá, PR, Brazil \\ ${ }^{2}$ State University of Maringá, Agronomic Science Department, Umuarama, PR, Brazil \\ Correspondence: Angélica Miamoto, Universidade Estadual de Maringá, Post-Graduate in Agronomy, Avenida \\ Colombo, n. 5790-Bloco J45, $2^{\circ}$ Piso, 87020-900, Maringá, Paraná, Brazil. Tel: 55-44-99904-4320. E-mail: \\ angelicamiamoto@gmail.com
}

Received: November 20, 2017

Accepted: December 22, 2017 Online Published: January 15, 2018

doi:10.5539/jas.v10n2p289

URL: https://doi.org/10.5539/jas.v10n2p289

\begin{abstract}
One of the main phytonematode control alternatives is the use of antagonistic plants in crop rotation or succession systems. Although java legume shows antagonist potential to control Meloidogyne javanica, its reaction to other nematodes was not investigated so far. Thus, the aim of the current study is to assess the penetration and reproduction factor (RF) of M. incognita, Rotylenchulus reniformis and Pratylenchus brachyurus in java, using soybean as control. Plants individually inoculated with 1000 specimens from each nematode were assessed 5, 10, 15, 20, 25 and 30 days after inoculation (DAI) for nematode penetration and development. The RF was assessed under two inoculum levels of each nematode (1000 and 700 specimens) 60 days after inoculation, for M. incognita and R. reniformis; and 80 days after inoculation, for P. brachyurus. Meloidogyne incognita and $R$. reniformis showed lower penetration and reproduction in java $(\mathrm{RF}<1)$, whereas $P$. brachyurus showed higher penetration and RF $>1$. Thus, the java legume can be considered resistant to $M$. incognita and $R$. reniformis, as well as susceptible to P. brachyurus.
\end{abstract}

Keywords: Macrotylloma axilare, Meloidogyne inconita, Pratylenchus brachyurus, Rotylenchulus reniformis, antagonism

\section{Introduction}

The cultivation of antagonistic plants through crop rotation or succession in order to control nematodes is cited as one of the most efficient practices, since it presents several positive results (Pudasaini et al., 2006; Oka, 2010; Santana et al., 2012a). Antagonist plants can be defined as those holding substances able to inhibit or affect the action of another living organism (Chitwood, 2002). Root exudates produced by these plants may have an allelopathic or even nematicidal effect; they also present mechanisms able to inhibit nematode development by interfering in their feeding process or interrupting their life cycle (Marla et al., 2008; Nyczepir \& Thomas, 2009; Andrade et al., 2010).

One of the main nematode control issues lies on the inadequate crop management, which worsens the problems they cause, specially in soybean crops (Glycine $\max (\mathrm{L}$.) Merril) because of mixed populations found in cultivated areas (Guzmán, 2011), and in Brazil the most common species are Meloidogyne javanica (Treub) Chitwood, M. incognita (Kofoid \& White) Chitwood, Pratylenchus brachyurus (Godfrey) Filipjev and Sch. Stekhoven, Heterodera glycines (Ichinohe), and Rotylenchulus reniformis (Linford \& Oliveira).

Some legumes may be used to control these nematode species and can act in different ways to control these parasites, including production of secondary metabolites with nematicidal effect in their roots and shoots. As exemple, there is the monocrotaline, which is a pyrrolizidine alkaloid (Colegate et al., 2012), produced by Crotalaria spp., able to cause egg and juvenile mortality or to change nematode reproduction (Wang et al., 2002; Marla et al., 2008; Leandro \& Asmus, 2015) and L-Dopa produced by mucuna (Mucuna spp. and Stizolobium spp.), which reduces the final nematode populations, increases mortality, and decreases femea Meloidogyne spp. formation (Barbosa et al., 1999). In addition, plants work as traps, since they attract juvenile nematodes and compromise their development after penetration (Curto et al., 2015; Miamoto et al., 2016). Antagonist plants may also be resistant to a particular pathogen, thus generating an incompatible reaction, called hypersensitivity reaction (HR), in which the programmed death of infected plant tissues happens as natural defense to pathogen 
attacks (Watanabe \& Lam, 2004). The HR may help restricting nematode infection or reproduction, since they are obligate parasites that feed on cellular compounds (Gabriel \& Rolfe, 1990; Williamson \& Kumar, 2006; Mur et al., 2008; Melillo et al., 2014).

Some legume species such as Macrotyloma axillare (E. Mey.) Verdc. cv. Java—or simply java—remain poorly studied. The aforementioned species, which was introduced in Brazil in 2004 (ABRASEM, 2006), is native to Indonesia and derives from the crossing between two M. axillare cultivars, namely: Archer and Guatá. It is a forage legume of perennial cycle, and does not demand high soil fertility in order to develop (Paiva et al., 2008). According to Miamoto et al. (2016), java plants may show antagonist potential, since M. javanica penetration per root gram was high, although the RF (reproduction factor) was low. In other words, this plant is highly attractive to M. javanica, sometimes even more attractive than soybean plants; however, it does not allow the nematode to complete its life cycle.

Thus, given the potential of java plants to control M. javanica, and due to the scarcity of studies focused on applying it in the management of other nematodes composing mixed populations in soybean crops, the aim of the current study was to assess $M$. incognita, $R$. reniformis and $P$. brachyurus penetration and reproduction in java plants.

\section{Materials and Methods}

The current experiment followed a completely randomized design and was conducted in a greenhouse at the State University of Maringá, located at latitude $23^{\circ} 47^{\prime} 28.4^{\prime \prime} \mathrm{S}$, longitude $53^{\circ} 15^{\prime} 24.0^{\prime \prime} \mathrm{W}$, and altitude $379 \mathrm{~m}$. Seedlings from java and soybean cultivar CD 206 (control) were germinated in polystyrene trays containing Bioplant ${ }^{\circledR}$ commercial substrate in order to assess nematode penetration in the experiment conducted with $M$. incognita. Similarly, seedlings from cultivar Pintado were used to assess nematode penetration in the experiment conducted with $R$. reniformis and P. brachyurus. Fifteen (15) days after germination, the aforementioned seedlings were transplanted into pots containing $700 \mathrm{~mL}$ soil (typical Dystrophic Red Latosol) sterilized through autoclaving at $120^{\circ} \mathrm{C}$ for 2 hours.

Two days after transplantation, they were inoculated with an initial $M$. incognita population (IP) comprising 700 eggs and eventual second-stage juveniles (J2), or with 700 R. reniformis or P. brachyurus specimens, in four holes open in the soil surrounding each plant. Pure M. incognita, R. reniformis and P. brachyurus populations were previously multiplied in tomato (cultivar Santa Clara), soybean (cultivar Pintado) and maize plants (cultivar Al Bandeirantes), respectively. They were extracted from the root system, according to the methodology by Hussey and Barker (1973), adapted by Boneti and Ferraz (1981) to be applied to M. incognita and R. reniformis, as well as by Coolen and D'Herde (1972) to P. brachyurus.

Four plants from each treatment were collected every five days, from the 5th to the 30th day after inoculation (DAI), for evaluation purposes. The root system of these plants was carefully separated from the shoot, washed and deposited on paper towel to remove the water excess. Next, the fresh root mass was set and the roots were, subsequently, stained with acid fuchsin, according to the method described by Byrd Junior et al. (1983), for further evaluation.

Temporary slides containing root fragments were mounted to assess the entire root volume. Meloidogyne incognita development stages $\mathrm{J} 2, \mathrm{~J} 3$, J4 (second-, third- and fourth-stage juveniles, respectively) and adult females; $R$. reniformis immature and adult females; as well as the total number of $P$. brachyurus nematodes penetrating the roots, were analyzed. The analyses were performed in a light microscope, at 100x magnification.

In addition to nematode penetration, java susceptibility to nematodes was tested at two inoculum levels. The same procedure adopted for seedling production, as well as the same cultivars, were applied to each nematode. Seedlings were transplanted to pots containing $700 \mathrm{~mL}$ autoclaved soil, 15 days after germination, as it was previously described. Two days after transplantation, java and soybean plants were inoculated with 700 or 1000 M. incognita eggs and occasional J2, or with 700 or 1000 R. reniformis or P. brachyurus specimens as previously described; the experiment adopted seven repetitions for each nematode species and for each inoculum level.

Assessments were conducted 60 (M. incognita and R. reniformis) and 80 days after inoculation (P. brachyurus). Plants were collected and their shoot was discarded. The root system of each plant was collected, carefully washed, and placed on absorbent paper to remove the water excess. Roots were weighed and subjected to the extraction processes mentioned above. Next, the total number of each nematode in the roots was assessed; such number was divided by the root mass in order to find nematodes/root gram. In addition, the reproductive factor $(\mathrm{RF})$ was calculated; RF = Final population/Initial population (Oostenbrink, 1966). Furthermore, $100 \mathrm{~cm}^{3}$ soil samples were collected and subjected to R. reniformis and P. brachyurus nematode extraction, according to the 
methodology by Jenkins (1964). In these cases, the total nematode population was calculated through the sum of total nematodes in the roots and in the soil. The analyses were conducted in Peters' slide, under optical microscope at $100 \times$ magnification.

Data were subjected to analysis of variance and compared, for each nematode and parameter, through Bonferroni T test, at 5\% probability level, in the Sisvar statistical software (Ferreira, 2014).

\section{Results}

Meloidogyne incognita did not show statistical difference in the number of $\mathrm{J} 2$, as well as in the total number of nematodes penetrating java roots, in comparison to soybean roots, at the 5th and 10th DAI. The number of nematodes per root gram was higher in the java root at the 10th DAI (Table 1). According to the assessments conducted in the 15th, 20th, 25th and 30th DAI, the number of J2, total nematode and nematode per root gram were larger in soybean plants, except at the 20th DAI, when there was no difference between treatments in the number of $\mathrm{J} 2$ and nematodes per root gram (Table 1).

Third-stage M. incognita juvenile (J3) formation started at the 15th DAI, both in soybean and java plants; the number of $\mathrm{J} 3$ in soybean roots was larger in all the herein assessed periods. The J4 formation started at the 15th DAI in soybean plants and at the 20th DAI in java plants (Figure 1). The largest number of J4 nematodes in soybean roots was recorded at the 20th and 25th DAI; however, this parameter did not show difference between treatments at the 30th DAI. The first adult females were recorded in soybean plants at the 20th DAI, whereas java plants presented female formation in the roots at the 25th DAI. The largest number of adult females was recorded in soybean plants at the 25th DAI (Figure 1); however, there was no difference between treatments at the 30th DAI (Table 1).

Table 1. Number of second- (J2), third- (J3) and fourth-stage (J4) female Meloidogyne incognita juveniles, total number of nematodes (TN) and nematodes per root gram (NRG) in the root system of java and soybean cultivar CD 206, assessed between the 5th and the 30th day after inoculation (DAI) with 700 nematode eggs and eventual juveniles

\begin{tabular}{|c|c|c|c|c|c|c|}
\hline Treatment & $\mathbf{J 2}$ & J3 & J4 & Female & TN & NRG \\
\hline \multicolumn{7}{|l|}{$5 D A I$} \\
\hline Java & $8.75^{\mathrm{ns}}$ & - & - & - & $8.75^{\mathrm{ns}}$ & $18.61 \mathrm{~b}$ \\
\hline Soybean & 3.50 & - & - & - & 3.50 & $1.95 \mathrm{a}$ \\
\hline MSD & 6.0 & - & - & - & 6.0 & 5.90 \\
\hline \multicolumn{7}{|l|}{$10 D A I$} \\
\hline Java & $3.50^{\mathrm{ns}}$ & - & - & - & $3.50^{\mathrm{ns}}$ & $5.36^{\mathrm{ns}}$ \\
\hline Soybean & 8.25 & - & - & - & 8.25 & 3.18 \\
\hline MSD & 6.79 & - & - & - & 6.79 & 4.50 \\
\hline \multicolumn{7}{|l|}{$15 D A I$} \\
\hline Java & $9.50 \mathrm{a}$ & $0.25 \mathrm{a}$ & $0.0^{\mathrm{ns}}$ & - & $9.75 \mathrm{a}$ & $5.49 \mathrm{a}$ \\
\hline Soybean & $29.25 \mathrm{~b}$ & $4.75 \mathrm{~b}$ & 0.50 & - & $34.50 \mathrm{~b}$ & $41.21 \mathrm{~b}$ \\
\hline MSD & 12.28 & 4.0 & 0.91 & - & 9.75 & 10.49 \\
\hline \multicolumn{7}{|l|}{$20 D A I$} \\
\hline Java & $12.75^{\mathrm{ns}}$ & $3.00 \mathrm{a}$ & $0.25 \mathrm{a}$ & $0.00^{\mathrm{ns}}$ & $16.00 \mathrm{a}$ & $9.61^{\mathrm{ns}}$ \\
\hline Soybean & 12.25 & $20.25 b$ & $14.75 \mathrm{~b}$ & 1.00 & $48.25 \mathrm{~b}$ & 10.40 \\
\hline MSD & 6.16 & 8.55 & 7.17 & 1.29 & 12.14 & 7.33 \\
\hline \multicolumn{7}{|l|}{$25 D A I$} \\
\hline Java & $3.50 \mathrm{a}$ & $2.75 \mathrm{a}$ & $1.25 \mathrm{a}$ & $0.25 \mathrm{a}$ & $7.75 \mathrm{a}$ & $7.31 \mathrm{a}$ \\
\hline Soybean & $23.75 \mathrm{~b}$ & $27.25 \mathrm{~b}$ & $23.25 \mathrm{~b}$ & $2.00 \mathrm{~b}$ & $76.25 \mathrm{~b}$ & $26.58 \mathrm{~b}$ \\
\hline MSD & 17.20 & 14.37 & 11.90 & 1.52 & 37.35 & 3.20 \\
\hline \multicolumn{7}{|l|}{$30 D A I$} \\
\hline Java & $3.50 \mathrm{a}$ & $1.50 \mathrm{a}$ & $1.50^{\mathrm{ns}}$ & $0.50^{\mathrm{ns}}$ & $7.00 \mathrm{a}$ & $2.26 \mathrm{a}$ \\
\hline Soybean & $99.75 \mathrm{~b}$ & $26.00 \mathrm{~b}$ & 3.00 & 3.00 & $131.75 \mathrm{~b}$ & $32.88 \mathrm{~b}$ \\
\hline MSD & 20.05 & 20.72 & 4.00 & 3.04 & 41.42 & 6.25 \\
\hline
\end{tabular}

Note. Means followed by the same letter did not differ from each other in the Bonferroni t-test, at $5 \%$ probability. $n s=$ not significant. MSD: minimum significant difference. 
There was no significant difference in the number of immature female $R$. reniformis nematodes in the assessments conducted at the 5th, 10th, 15th and 20th DAI; this number was larger in soybean plants at the 25th and 30th DAI, only (Table 2). Adult female formation was recorded in both cultures after the 15th DAI (Figure 2); this parameter did not show significant difference from the 15th DAI on (Table 2). There was also no difference between treatments in the total number of nematodes, according to the assessments conducted up to the 20th DAI. However, this variable presented higher values in soybean roots from the 25th DAI (Table 2). Java plants showed larger number of nematodes per root gram in the assessments conducted at the 5th, 10th, 15th and 20th DAI; however, this parameter presented higher values in soybean plants at the 30th DAI (Table 2).

Table 2. Number of immature Rotylenchulus reniformis females, adult females, total nematode (TN) and nematode per root gram (NRG) in the root system of java and soybean cultivar Pintado, assessed between the 5th and the 30th day after inoculation (DAI) with 700 specimens

\begin{tabular}{|c|c|c|c|c|}
\hline Treatment & Immature Females & Adult Females & TN & NRG \\
\hline \multicolumn{5}{|l|}{$5 D A I$} \\
\hline Java & $5.00^{\mathrm{ns}}$ & - & $5.00^{\text {ns }}$ & $13.22 \mathrm{~b}$ \\
\hline Soybean & 7.25 & - & 7.25 & $4.61 \mathrm{a}$ \\
\hline MSD & 13.08 & - & 13.08 & 6.84 \\
\hline \multicolumn{5}{|l|}{$10 D A I$} \\
\hline Java & $10.00^{\mathrm{ns}}$ & - & $10.00^{\mathrm{ns}}$ & $8.12 \mathrm{~b}$ \\
\hline Soybean & 18.25 & - & 18.25 & $4.39 \mathrm{a}$ \\
\hline MSD & 13.01 & - & 13.01 & 3.16 \\
\hline \multicolumn{5}{|l|}{$15 D A I$} \\
\hline Java & $16.50^{\text {ns }}$ & $0.25^{\mathrm{ns}}$ & $16.75^{\text {ns }}$ & $4.30 \mathrm{~b}$ \\
\hline Soybean & 22.00 & 1.75 & 23.75 & $2.47 \mathrm{a}$ \\
\hline MSD & 14.02 & 2.05 & 13.18 & 1.55 \\
\hline \multicolumn{5}{|l|}{$20 D A I$} \\
\hline Java & $11.75^{\text {ns }}$ & $0.00^{\mathrm{ns}}$ & $11.75^{\mathrm{ns}}$ & $3.41 \mathrm{~b}$ \\
\hline Soybean & 17.25 & 1.00 & 18.25 & $2.29 \mathrm{a}$ \\
\hline MSD & 15.50 & 1.29 & 14.37 & 1.00 \\
\hline \multicolumn{5}{|l|}{$25 D A I$} \\
\hline Java & $12.25 \mathrm{a}$ & $0.25^{\mathrm{ns}}$ & $12.50 \mathrm{a}$ & $2.15^{\mathrm{ns}}$ \\
\hline Soybean & $19.00 \mathrm{~b}$ & 1.00 & $20.00 \mathrm{~b}$ & 1.98 \\
\hline MSD & 4.75 & 2.38 & 4.94 & 1.43 \\
\hline \multicolumn{5}{|l|}{$30 \mathrm{DAI}$} \\
\hline Java & $11.00 \mathrm{a}$ & $0.25^{\mathrm{ns}}$ & $11.25 \mathrm{a}$ & $1.31 \mathrm{a}$ \\
\hline Soybean & $19.50 \mathrm{~b}$ & 1.25 & $20.75 \mathrm{~b}$ & $2.89 \mathrm{~b}$ \\
\hline MSD & 5.88 & 1.29 & 6.56 & 0.19 \\
\hline
\end{tabular}

Note. Means followed by the same letter did not differ from each other in the Bonferroni t-test, at $5 \%$ probability. ns $=$ not significant. MSD: minimum significant difference.

No statistical difference was observed in the total number of $P$. brachyurus penetrating java and soybean roots, according to assessments conducted at the 5th, 10th, 15th and 20th DAI (Table 3, Figure 3). However, the number of nematodes per root gram was larger in java than in soybean roots, according to assessments conducted at the 5th, 10th and 15th DAI (Table 3). Nonetheless, assessments performed at the 25th and 30th DAI showed that the total number of nematodes was larger in soybean roots, although the variable 'nematode per root gram' did not show difference between treatments (Table 3). 
Table 3. Total number of Pratylenchus brachyurus nematodes and nematodes per root gram (NRG) in the root system of java and soybean cultivar Pintado, assessed between the 5th and the 30th day after inoculation (DAI) with 700 specimens

\begin{tabular}{|c|c|c|}
\hline Treatment & Total number & NRG \\
\hline \multicolumn{3}{|l|}{$5 D A I$} \\
\hline Java & $102.75^{\mathrm{ns}}$ & $176.57 \mathrm{~b}$ \\
\hline Soybean & 62.25 & $95.72 \mathrm{a}$ \\
\hline DMS & 55.19 & 76.56 \\
\hline \multicolumn{3}{|l|}{$10 D A I$} \\
\hline Java & $39.50^{\text {ns }}$ & $95.20 \mathrm{~b}$ \\
\hline Soybean & 26.50 & $32.75 \mathrm{a}$ \\
\hline DMS & 29.25 & 29.85 \\
\hline \multicolumn{3}{|l|}{$15 D A I$} \\
\hline Java & $66.25^{\mathrm{ns}}$ & $122.40 \mathrm{~b}$ \\
\hline Soybean & 130.50 & $57.65 \mathrm{a}$ \\
\hline DMS & 120.21 & 33.37 \\
\hline \multicolumn{3}{|l|}{$20 D A I$} \\
\hline Java & $106.75^{\text {ns }}$ & $131.70^{\text {ns }}$ \\
\hline Soybean & 222.75 & 85.75 \\
\hline DMS & 137.93 & 63.47 \\
\hline \multicolumn{3}{|l|}{$25 D A I$} \\
\hline Java & $72.75 \mathrm{a}$ & $92.70^{\text {ns }}$ \\
\hline Soybean & $276.50 \mathrm{~b}$ & 76.07 \\
\hline DMS & 134.37 & 84.52 \\
\hline \multicolumn{3}{|l|}{$30 D A I$} \\
\hline Java & $39.75 \mathrm{a}$ & $34.55^{\text {ns }}$ \\
\hline Soybean & $140.25 b$ & 40.35 \\
\hline DMS & 83.47 & 24.97 \\
\hline
\end{tabular}

Note. Means followed by the same letter did not differ from each other in the Bonferroni t-test, at 5\% probability. ns $=$ not significant. MSD: minimum significant difference.

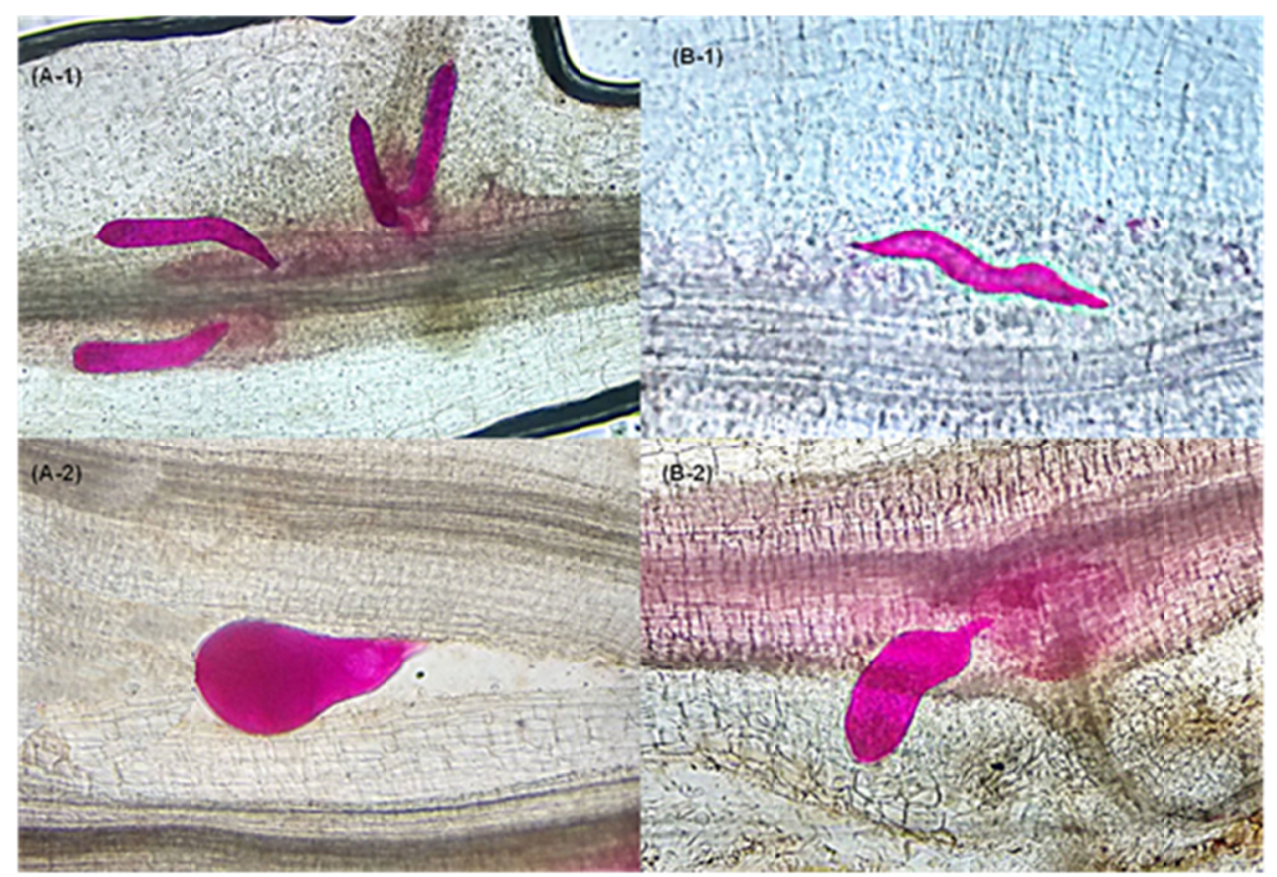

Figure 1. Meloidogyne incognita in soybean and java roots A-1: J3/J4 of M. incognita in soybean plant at the 15th DAI; A-2: M. incognita adult female in soybean plant at the 30th DAI; B-1: J3 of M. incognita in java plant at the 15th DAI; B-2: M. incognita immature female in java plant at the 30th DAI 


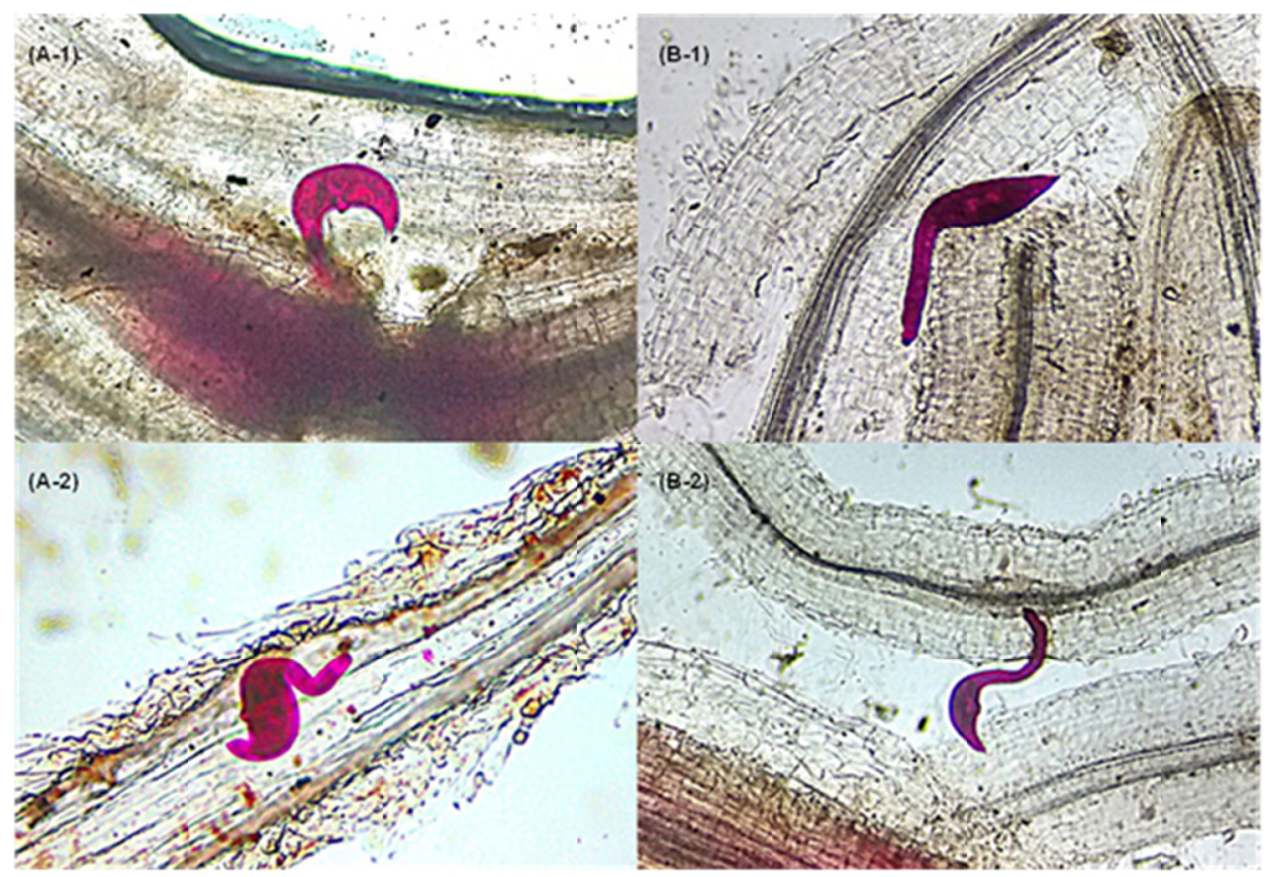

Figure 2. Rotylenchulus reniformis in soybean and java roots. A-1: $R$. reniformis adult female in soybean plant at the 15th DAI; A-2: $R$. reniformis adult female in soybean plant at the 30th DAI; B-1: $R$. reniformis immature female in java plant at the 15 th DAI; B-2: R. reniformis immature female in java plant at the 30th DAI

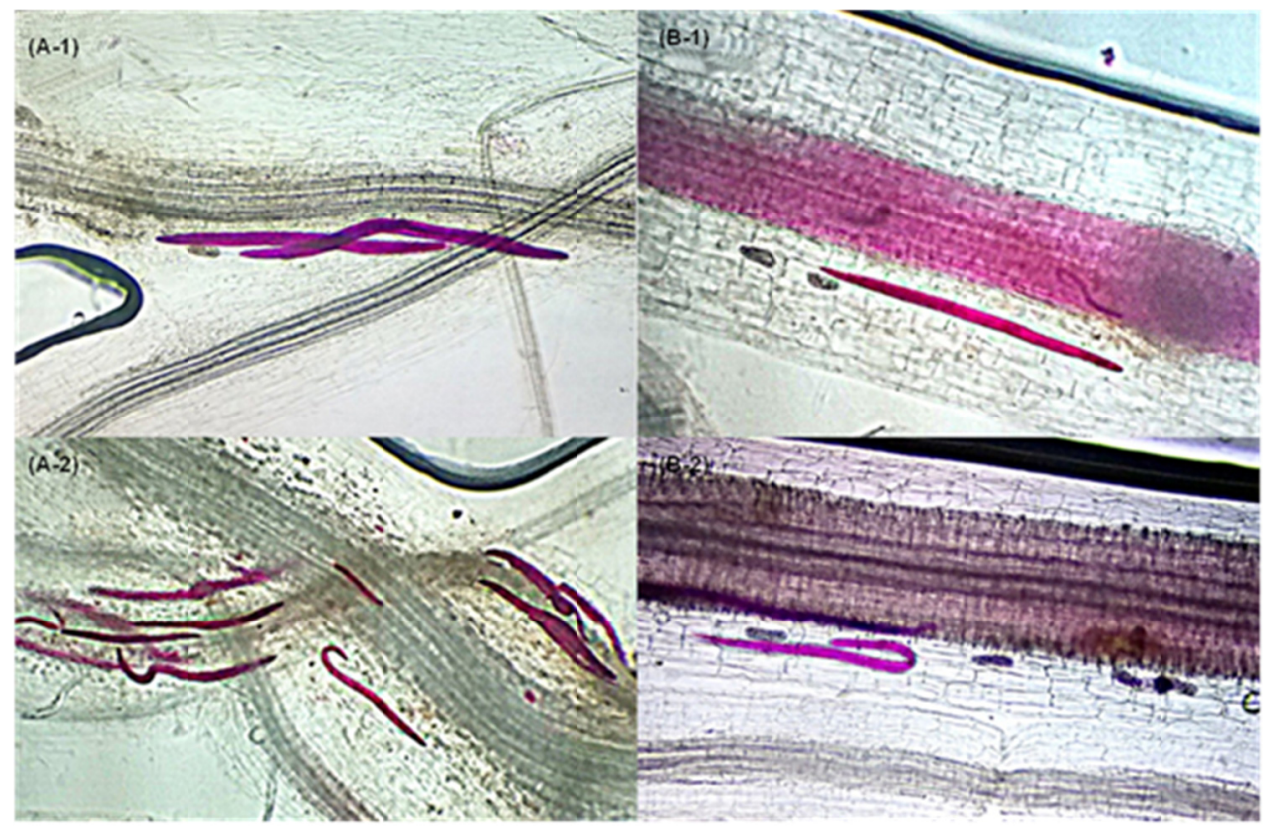

Figure 3. Pratylenchus brachyurus in soybean and java roots. A-1: P. brachyurus in soybean plant at the 15th DAI; A-2: P. brachyurus in soybean plant at the 30 th DAI; B-1: P. brachyurus in java plant at the 15 th DAI; B-2: $P$. brachyurus in java plant at the 30th DAI

With respect to the reproduction of the three nematode species studied, in plants inoculated with 700 specimens, the total number of nematodes and the number of nematodes per root gram were larger in soybean roots, used as control (Table 4). Java plants were susceptible to P. brachyurus $(\mathrm{RF}=1.87)$, although they showed RF lower than that recorded in soybean plants $(\mathrm{RF}=4.21)$. On the other hand, the herein assessed legume showed $\mathrm{RF}$ equal to 0.51 for $M$. incognita, as well as equal to 0.92 for $R$. reniformis (Table 4 ). 
Results recorded in plants inoculated with 1000 specimens were similar to the previously observed ones, i.e., variables "total nematodes" and "nematodes per root gram" presented the lowest values in java roots (Table 4). In addition, java plants confirmed susceptibility to P. brachyurus $(\mathrm{RF}=2.12)$, as well as resistance to $M$. incognita $(\mathrm{RF}=0.61)$ and to $R$. reniformis $(\mathrm{RF}=0.91)($ Table 4$)$.

Table 4. Total nematodes (TN), nematodes per root gram (NRG) and reproduction factor (RF) of Meloidogyne incognita, Rotylenchulus reniformis and Pratylenchus brachyurus, in java and soybean roots inoculated with initial population (IP) comprising 700 and 1000 specimens

\begin{tabular}{|c|c|c|c|}
\hline $\mathrm{IP}=\mathbf{7 0 0}$ & & & \\
\hline Treatment & TN & NRG & RF \\
\hline \multicolumn{4}{|l|}{ M. incognita } \\
\hline Java & $358 \mathrm{a}$ & $85 \mathrm{a}$ & $0.51 \mathrm{a}$ \\
\hline Soybean & $3101 \mathrm{~b}$ & $367 \mathrm{~b}$ & $4.43 \mathrm{~b}$ \\
\hline CV\% & 40.83 & 31.55 & 40.84 \\
\hline \multicolumn{4}{|l|}{ R. reniformis } \\
\hline Java & $650 \mathrm{a}$ & $25 \mathrm{a}$ & $0.92 \mathrm{a}$ \\
\hline Soybean & $1772 \mathrm{~b}$ & $84 \mathrm{~b}$ & $2.53 \mathrm{~b}$ \\
\hline CV\% & 17.30 & 37.81 & 17.30 \\
\hline \multicolumn{4}{|c|}{ P. brachyurus } \\
\hline Java & $1870 \mathrm{a}$ & $363 \mathrm{a}$ & $1.87 \mathrm{a}$ \\
\hline Soybean & $4217 \mathrm{~b}$ & $731 \mathrm{~b}$ & $4.21 \mathrm{~b}$ \\
\hline $\mathrm{CV} \%$ & 29.72 & 31.11 & 29.72 \\
\hline \multicolumn{4}{|l|}{$I P=1000$} \\
\hline Treatment & TN & NRG & RF \\
\hline \multicolumn{4}{|l|}{ M. incognita } \\
\hline Java & $614 \mathrm{a}$ & $183 \mathrm{a}$ & $0.61 \mathrm{a}$ \\
\hline Soybean & $3997 \mathrm{~b}$ & $908 \mathrm{~b}$ & $3.99 \mathrm{~b}$ \\
\hline $\mathrm{CV} \%$ & 18.20 & 77.80 & 3.99 \\
\hline \multicolumn{4}{|l|}{ R. reniformis } \\
\hline Java & $907 \mathrm{a}$ & $32 \mathrm{a}$ & $0.91 \mathrm{a}$ \\
\hline Soybean & $2318 b$ & $150 \mathrm{~b}$ & $2.37 \mathrm{~b}$ \\
\hline $\mathrm{CV} \%$ & 20.88 & 27.69 & 20.88 \\
\hline \multicolumn{4}{|c|}{ P. brachyurus } \\
\hline Java & $2120 \mathrm{a}$ & $603 \mathrm{a}$ & $2.12 \mathrm{a}$ \\
\hline Soybean & $6055 \mathrm{~b}$ & $1104 \mathrm{~b}$ & $6.05 \mathrm{~b}$ \\
\hline $\mathrm{CV} \%$ & 44.67 & 36.14 & 44.67 \\
\hline
\end{tabular}

Note. Means followed by the same letter did not differ from each other in the Bonferroni t-test, at $5 \%$ probability. $\mathrm{CV}=$ Coefficient of variation.

\section{Discussion}

The java legume proved to be resistant to $M$. incognita, since although adult females were formed, the total number of nematodes and nematodes per root gram at the end of the cycle was smaller than that recorded in soybean plants. Consequently, the low RF showed that nematode multiplication was negatively affected. However, java did not prevent the initial penetration; it was attractive to the nematode, but reduced its reproduction. These results corroborate those recorded for $M$. javanica, in which the number of nematodes per java root gram was larger than that recorded in soybean plants. Nevertheless, java was resistant to M. javanica $(\mathrm{FR}=0.12)$; although it is attractive to root-knot nematodes, it does not allow them to efficiently complete their life cycle (Miamoto et al., 2016). Nematodes belonging to genus Meloidogyne showed similar results in other pathosystems such as C. spectabilis Roth, $C$. juncea L. and C. paulina Scrank, which were attractive to $M$. javanica juveniles, allowed high penetration into the root system, but did not allow adult female formation up to the 45th DAI (Silva et al., 1989b). 
Thus, it is hypothesized that the action of java on M. incognita may be related to antagonistic substances affecting nematode development. Furthermore, it is possible inferring that the mechanism making this plant resistant is post-infectional and does not inhibit nematode penetration. In other words, nematodes penetrate the roots and induce the feeding site, but somehow such sites are not efficient in nurturing them or are inactivated by some plant resistance gene (Williamson \& Kumar, 2006). This type of reaction has been recorded in other studies conducted with Cajanus cajan (L.) Mill (pigeon pea) cv. Fava Larga — H. glycines (Valle et al., 1997) and Tagetes spp.-M. incognita, M. javanica, P. brachyurus and R. reniformis (Belcher \& Hussey, 1977; Bakker et al., 1979; Huang, 1984; Siddiqui \& Alam, 1987; Hussain et al., 2011). In the specific case of Tagetes spp., the antagonistic reaction results from alpha-tertienyl production, since this substance has direct effect on nematodes (Gommers \& Bakker, 1988).

Another hypothesis for the post-infection reaction is the activation of hypersensitivity reaction (HR) (Dhandaydham et al., 2008). This phenomenon is elucidated by the presence of resistance genes in the host $(\mathrm{H})$ and avirulence genes (Avr) in nematodes; the interaction between these genes triggers a cascade of plant defense responses (Fuller et al., 2008). The HR is initially triggered by the production of reactive oxygen species (ROS) (Mishra et al., 2012); it is followed by other molecular events such as the accumulation of salicylic acid, nitric oxide and different intracellular calcium levels (Muret et al., 2008). Such accumulation results in the localized and rapid death of cells composing the feeding site or of cells adjacent to it (Williamson, 1999), fact that is common in different associations between plants and nematodes (Branch et al., 2004; Anthony et al., 2005; Motta et al., 2012). This hypothesis is corroborated by histopathological analyses applied to C. spectabilis and C. juncea parasitized by M. javanica, in which the HR showed formation of giant cells, although in smaller number and size, with dense cytoplasm, few nuclei and, generally, without large vacuoles; such features may have made giant cells less efficient in the nematode nutrition process (Silva et al., 1990). The same type of reaction and histopathological features were recorded in tomatoes treated with resistance inducers against $M$. incognita, besides increased lignin in the nourishing cells (Melillo et al., 2014).

Java plants penetrated by $R$. reniformis showed $\mathrm{RF}<1$, which is the limit value for a plant to be considered resistant. Thus, it is necessary taking particular care at the time to plant this species in order to reduce the number of nematodes. It is possible saying that the java plant does not allow $R$. reniformis population increase, although it does not drastically reduce its population. Despite the scarcity of studies about $R$. reniformis antagonistic plants, there are reports about some species able to control it, namely: stylosanthes 'Campo Grande' (Stylosanthes capitata $\times$ S. macrocephala M. B. Ferreira \& N. M. Sousa Costa), peanut (Arachis hypogaea L.) and velvet bean (Mucuna deeringiana (Bort.) Merr); which were able to reduce the final parasite population in the field (Gardiano et al., 2014). Some crotalaria species are also cited as resistant to $R$. reniformis, since they present RF < 1 (Silva et al., 1989c; Leandro \& Asmus, 2015). Results reported for species C. juncea were similar to those recorded in the current study, i.e., the nematode was able to penetrate the roots; however, low reproduction rates and plant interference in female development were recorded (Wang et al., 2001; Marla et al., 2008).

Results showed that java was more attractive to P. brachyurus than soybean; however, java somehow reduced the reproductive rate of this nematode at the 80th DAI, since the RF was lower than that of the control, although it was higher than one. Antagonist plants negatively affect nematode population in different ways; one of them lies on attracting the parasite and allowing its penetration, but hindering its development and reproduction; these plants are also considered unfavorable hosts (Ferraz \& Valle, 1997). However, the term 'unfavorable host' or 'bad host' often refers to plants presenting lower RF, although close to 1.0, i.e., plants considered resistant (Wang et al., 2002). Thus, researchers consider some botanic species moderate hosts, since they present RF higher than 1.0, although significantly lower than that recorded in the control (Inomoto et al., 2006; Machado et al., 2007; Borges et al., 2010). These studies corroborate the current results, since java plants presented RF values 1.87 and 2.12 when they were inoculated with 700 and 1000 specimens, respectively, and were considered susceptible to the nematode (Oostenbrink, 1966); however, java RF values were significantly lower than those recorded in soybean plants (4.21 and 6.05) inoculated with the respective inoculum levels. Similar reproduction factor was recorded in C. cajan cv. Fava Larga $(\mathrm{RF}=1.57)$ inoculated with P. brachyurus (Inomoto et al., 2006). However, this cultivar was assessed against two P. brachyurus isolates from different regions- $\mathrm{Pb} 20$ and $\mathrm{Pb} 24$-and presented RF 0.78 and 4.28, respectively, whereas the respective values for soybean cv. Pintado were 1.60 and 6.15 (Machado et al., 2007).

Plants with potential to control other nematode species may respond differently to P. brachyurus or even to distinct populations of this species, as it was observed in C. cajan cv. 'IAPAR 43', which enabled Meloidogyne ethiopica Whitehead and R. reniformis control (Lima et al., 2009; Gardiano et al., 2012). Similar result was 
recorded for C. juncea, which allowed reducing M. javanica populations (Inomoto et al., 2008; Miamoto et al., 2016), although it was not efficient in controlling P. brachyurus (Braz et al., 2016). It is worth highlighting that C. juncea recorded different RFs for different P. brachyurus populations; populations from Goiás State presented $\mathrm{RF}=2.16$ (Braz et al., 2016), those from Rio de Janeiro State recorded $\mathrm{RF}=1.13$, and populations from Mato Grosso State recorded 4.27 (Machado et al., 2007). Thus, it is common for antagonist plants to present varying reactions when they are exposed to a specific nematode genus, species or population; at first, such variation may appear to be more prominent in nematodes with migratory feeding habit.

It is worth pinpointing that plants whose RF is higher than 1, even when this value is lower than that of the susceptible plant, should be carefully used or analyzed in the field, since assessments under experimental conditions are often carried out between the 60th and 90th days after inoculation. However, there are some examples such as the black velvet (Stizolobium aterrimum Piper and Tracy), in which P. zeae Graham showed $\mathrm{RF}=1.76$ at the 60th DAI. This value was lower than that recorded for maize, which was used as control $(\mathrm{RF}=$ 36.40); however, $P$. zeae showed RF $=16.69$ at the 110th DAI, when it did not statistically differ from maize, which showed RF $=20.40$ (Santana et al., 2012a).

It is essential conducting further studies to help better understanding the mode of action of antagonistic plants on migratory nematodes, since their behavior overall differs from that observed in the sedentary ones. In this case, C. spectabilis may be used as an example, although it reduces P. brachyurus reproduction (Santana et al., 2012b; Rosa et al., 2013; Debiasi et al., 2016). Such activity is attributed to the low attractiveness of the plant or even to its higher resistance to P. brachyurus and P. zeae penetration (Silva et al. 1989a; Santana et al. 2012a). Differently, crotalaria plants are attractive to sedentary nematodes; however, they present giant cell dysfunction, fact that makes them less efficient in feeding the parasite (Silva et al., 1990).

Java plants do not prevent $M$. javanica and $R$. reniformis penetration; however, it is considered resistant to both nematodes, since it shows reproduction factor lower than 1 . Thus, it is necessary conducting additional studies with R. reniformis, since the herein recorded reproductive factor was very close to 1 . Java is susceptible to $P$. brachyurus, although it presents reproduction factor lower than that recorded for soybean plants.

\section{References}

ABRASEM (Associação Brasileira de Sementes e Mudas). (2006). Consolidando o Sistema Sementeiro junto ao Agronegócio Nacional: Anuário 2006. Retrieved July 20, 2017, from http://www.abrasem.com.br

Andrade, L. B. S., Oliveira, A. S., Ribeiro, J. C., Kiyota, S., Vasconcelos, I. M., Oliveira, J. T. A., \& Sales, M. P. (2010). Effects of a novel pathogenesis-related class 10 (PR-10) protein from Crotalaria pallida roots with papain inhibitory activity against root-knot nematode Meloidogyne incognita. Journal of Agricultural and Food Chemistry, 58(7), 4145-4152. https://doi.org/10.1021/jf9044556

Anthony, F., Topart, P., Martinez, A., Silva, M., \& Nicole, M. (2005). Hypersensitive-like reaction conferred by de Mex-1 resistance gene against Meloidogyne exigua in coffee. Plant Pathology, 54(4), 476-482. https://doi.org/10.1094/PHYTO-08-14-0232-R

Bakker, J., Gommers, F. J., Nieuwenhuis, I., \& Wynberg, H. (1979). Photoactivation of the nematicidal compound alfa-terthienyl from roots marigolds (Tagetes species). A possible singlet oxygen role. Journal of Biological Chemistry, 254(6), 1841-1844.

Barbosa, L. C. A., Barcelos, F. E., Demuner, A. J., \& Santos, M. A. (1999). Chemical constituints from Mucuna aterrima with activity against Meloidogyne incognita and Heterodera glycines. Nematropica, 29(1), 81-88.

Belcher, J. V., \& Hussey, R. S. (1977). Influence of Tagetes patula and Arachis hypogeae on Meloidogyne incognita. Plant Disease Report, 61(1), 525-528.

Boneti, J. I. S., \& Ferraz, S. (1981). Modificação do método de Hussey e Barker para extração de ovos de Meloidogyne exigua de raízes de cafeeiro. Fitopatologia Brasileira, 6(1), 553.

Borges, D. C., Machado, A. C. Z., \& Inomoto M. M. (2010). Reação de aveias a Pratylenchus brachyurus. Tropical Plant Pathology, 35(3), 178-181. https://doi.org/10.1590/S1982-56762010000300007

Branch, C., Hwang, C. F., Navarre, D. A., \& Williamson, V. M. (2004). Salicylic acid in part of the Mi-1-mediated defense response to root-knot nematode in tomato. Molecular Plant-Microbe Interactions Journal, 17(4), 351-357. https://doi.org/10.1094/MPMI.2004.17.4.351

Braz, G. B. P., Oliveira Jr., R. S., Constantin, J., Raimondi, R. T., Ribeiro, L. M., Gemelli, A., \& Takano, H. K. (2016). Weeds as alternative hosts for Pratylenchus brachyurus. Summa Phytopathology, 42(3), 233-238. https://doi.org/10.1590/0100-5405/2129 
Byrd Junior, D. W., Kirpatrick, J., \& Barker, K. R. (1983). An improved technique for clearing and staining plant tissues for detection of nematodes. Journal of Nematology, 15(1), 142-143.

Chitwood, D. J. (2002). Phytochemical based strategies for nematode control. Annual Review of Phytopathology, 40(1), 221-249. https://doi.org/10.1146/annurev.phyto.40.032602.130045

Colegate, S. M., Gardner, D. R., Joy, R. J., Betz, J. M., \& Panter, K. E. (2012). Dehydropyrrolizidine alkaloids, including monoesters with an unusual esterifying acid, from cultivated Crotalaria juncea (sunn hemp cv. 'Tropic Sun'). Journal of Agricultural and Food Chemistry, 60(14), 3541-3550. https://doi.org/10.1021/ jf205296s

Coolen, W. A., \& D'Herde, C. J. (1972). A method for the quantitative extration of nematodes from plant tissue. Belgium: Ghent.

Curto, G., Dallavalle, E., Santi, R., Casadei, N., D’Avino, L., \& Lazzeri, L. (2015). The potential of Crotalaria juncea L. as a summer green manure crop in comparison to Brassicaceae catch crops for management of Meloidogyne incognita in the Mediterranean area. European Journal of Plant Pathology, 142(4), 829-841. https://doi.org/10.1007/s10658-015-0655-2

Debiasi, H., Franchini, J. C., Dias, W. P., Ramos Junior, E. U., \& Balbinot Junior, A. A. (2016). Práticas culturais na entressafra da soja para o controle de Pratylenchus brachyurus. Pesquisa Agropecuária Brasileira, 51(10), 1720-1728. https://doi.org/10.1590/s0100-204x2016001000003

Dhandaydham, M., Charles, L., Zhu, H., Starr, J. L., Huguet, T., Cook, D. R., ... Opperman, C. (2008). Characterization of root-knot nematode resistance in Medicago truncatula. Journal of Nematology, 40(1), 46-54.

Ferraz, S., \& Valle, L. A. C. (1997). Controle de fitonematóides por plantas antagônicas. Viçosa: UFV.

Ferreira, D. F. (2014). Sisvar: A Guide for its Bootstrap procedures in multiple comparisons. Ciência e Agrotecnologia, 38(2), 109-112. https://doi.org/10.1590/S1413-70542014000200001

Fuller, V. L., Lilley, C. J., \& Urwin, P. E. (2008). Nematode Resistance. New Phytologist, 180(1), $27-44$. https://doi.org/10.1111/j.1469-8137.2008.02508.x

Gabriel, D. W., \& Rolfe, B. G. (1990). Working models of specific recognition in plant-microbe interactions. Annual Review of Phytopathology, 28(1), 365-391. https://doi.org/10.1146/annurev.py.28.090190.002053

Gardiano, C. G., Krzyzanowski, A. A., \& Saab, O. J. G. A. (2012). Hospedabilidade de plantas melhoradas de solo à Rotylenchulus reniformis Lindorf e Oliveira (1940). Arquivos do Institudo Biológico, 79(2), 313-317. https://doi.org/10.1590/S1808-16572012000200025

Gardiano, C. G., Krzyzanowski, A. A., \& Saab, O. J. G. A. (2014). Efficiency of green manure species on the population of reniform nematode. Semina Ciências Agrárias, 35(2), 719-726. https://doi.org/10.5433/ 1679-0359.2014v35n2p719

Gommers, F. J., \& Bakker J. (1988). Physiological changes induced by plant responses or products. In G. O. Poinar Jr. \& H. B. Jansson (Eds.), Diseases of nematodes (pp. 46-49). Boca Raton: CRC Press Inc.

Guzmán, P. O. (2011). El nematodo Barrenador (Radopholus simili Thorne) Del banano y plátano. Luna Azul, $32(1), 137-153$

Huang S. P. (1984). Cropping Effects of Marigolds, Corn, and Okra on Population Levels of Meloidogyne javanica and on Carrot Yields. Journal of Nematology, 16(4), 396- 398.

Hussain, M. A., Mukhtar, T., \& Kayani M. Z. (2011). Efficacy evaluation of Azadirachta indica, Calotropis procera, Datura stramonium and Tagetes erecta against Root-knot nematodes Meloidogyne incognita. Pakistan Journal of Botanical, 43(1), 197-204.

Inomoto, M. M., Antedomênico, S. R., Santos, V. P., Silva, R. A., \& Almeida, G. C. (2008). Greenhouse evaluation of the potential of sorghum, pearl millet and crotalaria in the management of Meloidogyne javanica. Tropical Plant Pathology, 33(2), 125-129. https://doi.org/10.1590/S1982-56762008000200006

Inomoto, M. M., Motta, L. C. C., Machado, A. C. Z., \& Sazaki, C. S. S. (2006). Reação de dez coberturas vegetais a Pratylenchus brachyurus. Nematologia Brasileira, 30(2), 151-157.

Jenkins, W. R. A. (1964). A rapid centrifugal-flotation technique for separating nematodes from soil. Plant Disease Report, 48(1), 692. 
Kumar, A. R., Kumar, N., Poornima, K., \& Soorianathasundaram, K. (2008). Screening of in-vitro derived mutants of banana against nematodes using bio-chemical parameters. American-Eurasian Journal of Sustainable Agriculture, 2(3), 271-278. https://doi.org/10.5897/AJB08.587

Leandro, H. M., \& Asmus, G. L. (2015). Crop rotation and crop sequences for the management of the reniform nematode in area of soybean production. Ciência Rural, 45(6), 945-950. https://doi.org/10.1590/ 0103-8478cr20130526

Lima, E. A., Mattos, J. K., Moita, A. W., Carneiro, R. G., \& Carneiro, R. M. D. G. (2009). Host status of different crops for Meloidogyne ethiopica control. Tropical Plant Pathology, 34(3), 152-157. https://doi.org/ 10.1590/S1982-56762009000300003

Machado, A. C. Z., Motta, L. C. C., Siqueira, K. M. S., Ferraz, L. C. C. B., \& Inomoto M. M. (2007a). Host status of green manures for two isolate of Pratylenchus brachyurus in Brazil. Nematology, 9(6), 799-805. https://doi.org/10.1163/156854107782331153

Marla, S. R., Huettel, R. N., \& Mosjidis, J. (2008). Evaluation of Crotalaria juncea populations as hosts and antagonistic crops to manage Meloidogyne incognita and Rotylenchulus reniformis. Nematropica, 38(2), 155-161.

Melillo, M. T., Leonetti, P., \& Veronico, P. (2014). Benzothiadiazole effect in the compatible tomatoMeloidogyne incognita interaction: Changes in giant cell development and priming of two root anionic peroxidases. Planta, 240(4), 841-854. Https://doi.org/10.1007/s00425-014-2138-7

Miamoto, A., Dias-Arieira, C. R., Cardoso, M. R., \& Puerari, H. H. (2016). Penetration and reproduction of Meloidogyne javanica on leguminous crops. Journal of Phytopathology, 164(11-12), 890-895. https://doi.org/10.1111/jph.12508

Mishra, A. K., Sharma, K., \& Misra, R. S. (2012). Elicitor recognition, signal transduction and induced resistance in plants. Journal of Plant Interactions, 7(2), 95-120. https://doi.org/10.1080/17429145.2011. 597517

Motta, F. C., Alves, G. C. S., Giband, M., Gomes, A. C. M. M., Souza, F. R., Mattos, V. S., ... Carneiro, R. M. D. G. (2012). New sources of resistance to Meloidogyne incognita race 3 in wild cotton accessions and histological characterization of the defence mechanisms. Plant Pathology, 62(5), 1173-1183. https://doi.org/ $10.1111 /$ ppa.12022

Mur, L. A. J., Kenton, P., Lioyd, A. J., Oughan, H., \& Prats, E. (2008). The hypersensitive response: The centenary is upon us but how much do we know? Journal of Experimental Botany, 59(3), 501-520. https://doi.org/10.1093/jxb/erm239

Nyczepir, A. P., \& Thomas, S. H. (2009). Current and future management strategies in intensive crop production systems. In R. N. Perry, M. Moens, \& J. L. Starr (Eds.), Root-knot nematodes (pp. 421-443). United Kingdom: CABI. https://doi.org/10.1079/9781845934927.0412

Oka, Y. (2010). Mechanisms of nematode suppression by organic soil amendments: A review. Applied Soil Ecology, 44(2), 101-115. https://doi.org/10.1016/j.apsoil.2009.11.003

Oostenbrink, R. (1966). Major characteristics of the relation between nematodes and plants. Meded Land-Bouwhogeschool, 66(4), 46.

Paiva, A. S., Rodrigues, R. J. D., Canciana, A. J., Lopes, M. M., \& Fernandes, A. C. (2008). Physiological and physical quality of seed of the forage legume Macrotyloma axillare cv. Java. Revista Brasileira de Sementes, 30(2), 130-136. https://doi.org/10.1590/S0101-31222008000200016

Pudasaini, M. P., Viaene, M., \& Moens, M. (2006). Effect of marigold (Tagetes patula) on population dynamics of Pratylenchus penetrans, in a field. Nematology, 8(4), 477-484. https://doi.org/10.1163/1568541067 78613930

Rosa, J. M. O., Westerich, J. N., \& Wilcken, S. R. S. (2013). Meloidogyne javanica reproduction on vegetable crops and plants used as green manure verde. Tropical Plant Pathology, 38(2), 133-141. https://doi.org/ 10.1590/S1982-56762013000200007

Santana, S. M., Dias-Arieira, C. R., Biela, F., Cunha, T. P. L., Chiamolera, F. M., Puerari, H. H., \& Fontana, L. F. (2012a) Root lesion nematodes management with antagonistic plants in sugarcane growing areas. Nematropica, 42(1), 63-71. 
Santana, S. M., Dias-Arieira, C. R., Biela, F., Cunha, T. P. L., Chiamolera, F. M., Roldi, M., \& Abe, V. H. F. (2012b). Antagonistic plants in the management of Meloidogyne incognita, in sandy soil of vegetables growing areas. Nematropica, 42(2), 287-294.

Siddiqui, M. A., \& Alam, M. M. (1987). Utilization of Marigold Plant Wastes for the Control of Plant Parasitic Nematodes. Biological Wastes, 21(3), 221-229. https://doi.org/10.1016/0269-7483(87)90128-5

Silva, G. S., Ferraz, S., \& Santos, J. M. (1989c). Resistência de espécies de Crotalaria a Rotylenchulus reniformis. Nematologia Brasileira, 13(1), 87-92.

Silva, G. S., Ferraz, S., \& Santos, J. M. (1989a). Resistance of Crotalaria species to Pratylenchus brachyurus and P. zeae. Nematologia Brasileira, 13(1), 81-86.

Silva, G. S., Ferraz, S., \& Santos, J. M. (1989b). Atração, penetração e desenvolvimento de larvas de Meloidogyne javanica em raízes de Crotalaria spp. Nematologia Brasileira, 13(1), 151-163.

Silva, G. S., Ferraz, S., \& Santos, J. M. (1990). Histopatologia de raízes de Crotalaria parasitadas por Meloidogyne javanica. Fitopatologia Brasileira, 15(1), 46-48.

Valle, L. A. C., Ferraz, S., \& Teixeira, D. A. (1997). Estímulo à eclosão de juvenis, penetração e desenvolvimento de Heterodera glycines em raízes de mucuna preta (Mucuna aterrima) e feijão guandu (Cajanus cajan). Nematologia Brasileira, 21(1), 67-83.

Wang, K. H., Sipes, B. S., \& Schmitt, D. P. (2001). Suppression of Rotylenchulus reniformis by Crotalaria juncea, Brassica napus, and Tagetes erecta. Nematropica, 31(2), 235-249.

Wang, K. H., Sipes, B. S., \& Schmitt, D. P. (2002). Crotalaria as a cover crop for nematode management. Nematropica, 32(1), 35-57.

Watanabe, N., \& Lam, E. (2004). Recent advance in the study of caspase-like proteases and Bax inhibitor-1 in plants: Their possible roles as regulator of programmed cell death. Molecular Plant Pathology, 5(1), 65-70. https://doi.org/10.1111/j.1364-3703.2004.00206.x.

Williamson, V. M. (1999). Plant nematode resistance genes. Current Opinion in Plant Biology, 2(4), $327-331$. https://doi.org/10.1016/S1369-5266(99)80057-0

Williamson, V. M., \& Kumar, A. (2006). Nematode resistance in plants: the battle underground. Trends Genetics, 22(7), 396-403. https://doi.org/10.1016/j.tig.2006.05.003

\section{Copyrights}

Copyright for this article is retained by the author(s), with first publication rights granted to the journal.

This is an open-access article distributed under the terms and conditions of the Creative Commons Attribution license (http://creativecommons.org/licenses/by/4.0/). 